ENTREPRENEURSHIP AND SUSTAINABILITY ISSUES

ISSN 2345-0282 (online) http://jssidoi.org/jesi/ 2020 Volume 8 Number 1 (September)

http://doi.org/10.9770/jesi.2020.8.1(63)

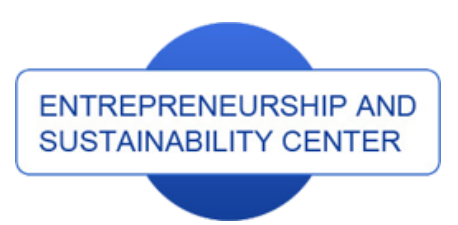

Publisher

http://jssidoi.org/esc/home
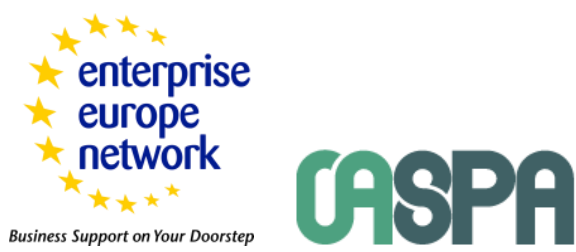

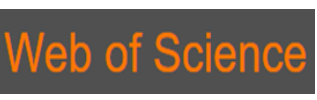

Clarivate
Analytics

\title{
PROBLEMS OF BUSINESS PROCESSES TRANSFORMATION IN THE CONTEXT OF BUILDING
} DIGITAL ECONOMY

\author{
Karine Alexandrovna Barmuta ${ }^{1}$, Elvir Munirovich Akhmetshin ${ }^{2 *}$, Iryna Yevheniivna Andryushchenko ${ }^{3}$, \\ Asiyat Akhmedovna Tagibova ${ }^{4}$, Galina Vladimirovna Meshkova ${ }^{5}$, Angelina Olegovna Zekiy ${ }^{6}$ \\ ${ }^{1}$ Don State Technical University, Gagarin Sq., 1, Rostov-on-Don, 344000, Russia \\ ${ }^{2}$ Kazan Federal University, Elabuga Institute of KFU, Kazanskaya Street, 89, 423604, Elabuga, Russia \\ ${ }^{3}$ National University “Zaporizhzhia polytechnic”, Zhukovskogo str., 64, Zaporizhzhia, Zaporizhia Oblast, Ukraine \\ ${ }^{4}$ Moscow State Institute of International Relations (MGIMO), Prospect Vernadskogo, 76, 119454, Moscow, Russia \\ ${ }^{5}$ Bauman Moscow State Technical University, 2nd Baumanskaya street, 5, p. 1, 105005, Moscow, Russia \\ ${ }^{6}$ Sechenov First Moscow State Medical University, Trubetskaya street, 8-2, 119991, Moscow, Russia \\ E-mail: ${ }^{2 *}$ elvir@mail.ru (Corresponding author)
}

Received 16 December 2020; accepted 24 April 2020; published 30 June 2020

\begin{abstract}
The article explores the main problems and features of one of the most relevant phenomena today - digital transformation, which implies fundamental changes in the activities of organizations based on the use of digital technologies. The paper reviews sources on the problems of building a digital economy and moving a business to the digital level. The purpose of this study is to identify the main difficulties for the restructuring of organizations' processes on a digital format, as well as the formation of the theoretical and conceptual foundations of digital business transformation in the face of uncertainty and variability of the modern business environment. Using the methods of analysis, generalization, comparison, synthesis, deduction, induction, the essence of digital transformation is studied, Russia's positions among other countries in terms of readiness for the digital economy are analyzed, problems and barriers that impede the process of digital transformation for Russian and foreign companies are formulated. Based on the use of a systematic approach, methods of scientific abstraction, economic modelling, the work identifies the main functional areas of change, presents a loop of digital business transformation that reflects its main stages, necessary components and changes, and describes key segments of new digital business models of companies. The results can be used to conduct further theoretical and methodological and practice-oriented research in the field of digital business transformation, and can also be used by design teams of organizations to analyze the problems of switching to a digital format, develop a digital transformation strategy and rebuild a business model.
\end{abstract}

Reference to this paper should be made as follows: Barmuta, K. A., Akhmetshin, E. M., Andryushchenko, I. E., Tagibova, A. A., Meshkova, G. V., Zekiy, A. O. (2020). Problems of business processes transformation in the context of building digital economy. Entrepreneurship and Sustainability Issues, 8(1), 945-959. http://doi.org/10.9770/jesi.2020.8.1(63)

JEL Classifications: M21; O10; O39. 


\section{ENTREPRENEURSHIP AND SUSTAINABILITY ISSUES}

ISSN 2345-0282 (online) http://jssidoi.org/jesi/

2020 Volume 8 Number 1 (September)

http://doi.org/10.9770/jesi.2020.8.1(63)

\section{Introduction}

Digitalization leads to large-scale changes in business and society, which are becoming permanent. Markets are gradually being filled with digital products and services, necessitating a change in traditional business models (Belk, 2013; Prause, 2015; Petrenko et al., 2019). Transformation provides organizations with opportunities for business development, setting and achieving new goals, moving to a new level of implementing routine functions. The future of the economy of any country depends on the ability of enterprises and companies of all forms to successfully transform into a digital business environment. This determines the relevance and importance of researching issues related to the nature and categorical apparatus of the digital economy, as well as the difficulties and possibilities of moving to the digital level.

Currently, one of the most significant phenomena in the scientific and business environment is the digital transformation, reflecting the changes in society and economy due to the development of digital technologies (Gapsalamov et al., 2020; Minakhmetova et al., 2020). However, the results of numerous studies (McKeown \& Philip, 2003; Svahnetal, 2017; Avdeyeva et al., 2019; Laužikas, Miliūtè, 2020) show that technology is only a component of transformation that ensures the organization's continued competitiveness in the digital economy. To move to the digital level, it is also necessary to create and develop an appropriate strategy, culture, infrastructure, and outline a new business model. Based on this, the purpose of this study is to identify barriers to the restructuring of companies' processes for a digital format, as well as the formation of the theoretical and conceptual foundations of digital business transformation in the face of uncertainty, mobility and complexity of the modern business environment.

\section{Literature review}

It should be noted that digitalization is not a completely innovative phenomenon, since the digitally-oriented activity aimed at collection, processing, analysis and use of data has been ongoing since the 1960s. However, the innovative aspect of digitalization is the speed and content of changes caused by the use of new technologies (Babkin, Chistyakova, 2017; Dokka et al., 2020; Savina, 2019; Bykanova and Akhmadeev, 2019).

For some time, studies of digital transformation have been conducted to a greater extent by practitioners, and only in the latest decade many foreign and Russian scientists have paid attention to this category, studying its content, problems and implementation possibilities.

The essence, features, key elements and prospects of building a digital economy has been the object of studies of such scientists as Amelin S.V. and Schetinina I. V. (2018), Asadullina S.V. (2018), Babkin A.V. et al., (2017), Dobrynin A.P. et al., (2016), Morrar, R. (2017), Manyika J. (2016), Mousa S. (2017), Korableva O.N. et al., (2019), Lettl C. (2018), Ritter T. (2018), Ross J.W. (2017), etc.

A universal and generally accepted definition of digital transformation does not currently exist, however, based on an analysis of the interpretations developed by various scientists, it is safe to conclude that digital transformation is a more complex type of technology-based business transformation than, for example, restructuring or reorganization, which requires rethinking the strategic roles of new digital technologies and the opportunities for successful implementation of digital innovation policy (Ismail et al., 2018; Parviainen et al., 2017; Voronkova et al., 2020; Samusenko et al., 2020). According to Russian scientists S.V. Amelin, I.V. Shchetinina (2018), digital transformation involves revolutionary changes in the business models of organizations based on the use of digital platforms in order to ensure significant growth in market volumes by increasing the competitiveness of products (Amelin, Schetinina, 2018). A group of German scientists (Bloching et. Al., 2015) understands by digital transformation the continuous interaction of all business sectors, providing for adaptation to the requirements of 


\section{ENTREPRENEURSHIP AND SUSTAINABILITY ISSUES}

ISSN 2345-0282 (online) http://jssidoi.org/jesi/ 2020 Volume 8 Number 1 (September) http://doi.org/10.9770/jesi.2020.8.1(63)

the digital economy. According to a number of scientists (Berman, 2012; Vial, 2019; Boston Consulting Group: Digital transformation over view), the transformation reflects a process in which companies converge many new technologies to significantly improve operational activities and achieve sustainable competitiveness by changing various business functions.

It should be noted that during a review of sources devoted to digital transformation, it was revealed that many organizations do not appreciate the benefits of digital transformation and are not ready to switch to a digital format of activity (Galimova, 2019; Asadullina, 2018; Popok et al., 2020; Kazmina et al., 2020a,b; Lenka et al., 2017; Working Paper: Digital Economy - Facts \& Figures). Many issues relating directly to the digital transformation process, the development of a digital culture, changing the business model and actually building a business based on digital technologies in general, remain insufficiently covered in the scientific and business literature, which confirms the relevance and need for further research in this area.

\section{Methodology}

The methodological system of the study is based on the application of a systematic approach, methods of scientific abstraction, economic modeling in the analysis and construction of the conceptual foundations of digital business transformation. The reliability of the research results is ensured by the use of appropriate methods of scientific research: generalization, analysis, synthesis, induction and deduction, analogy.

The information and analytical base of the study is compiled by official statistics from the Russian Federation and international organizations, as well as results reported in research papers, articles by foreign and Russian scientists, and materials from periodicals. Russia's positions in the field of digitalization were estimated using statistical methods based on a comparison of various indicators of readiness for the digital economy with the indicators of other countries. Among the evaluation criteria, the following were used:

- the use of modern systems to automate the planning, management and implementation of business processes in Russian organizations;

- the number of people with any digital skills;

- use of the Internet to make online purchases;

- digitalization index, an aggregate indicator of digital competencies of personnel of organizations, the use of digital technologies and the level of cybersecurity.

For analysis, comparison and generalization of information, data was sampled from reports, statistical digests and scientific papers on the following key issues and topics:

- experience of foreign and Russian companies in the development and use of strategies for implementing digital transformation;

- the reasons that motivate the decision to take the business to the digital level;

- digitalization of organizations levels (degrees);

- basic difficulties that companies faced during the digital transformation of business.

The use of logical, analytical and integrated methods enabled us to identify key functional areas in a company that need to be changed in the process of digital transformation, including management, operations, production sphere, customer interaction, organizational issues and information management elements. The analysis of the data arrays on the issues of the effectiveness of digital transformations in various organizations revealed the main barriers preventing companies from effectively transferring business activity to the digital level, features and aspects of company activities during digital development.

Using inductive and synthetic methods of scientific research, the key segments of the new business model were formed in the study, taking into account the changes necessary for the digital transformation. The traditional 


\section{ENTREPRENEURSHIP AND SUSTAINABILITY ISSUES}

ISSN 2345-0282 (online) http://jssidoi.org/jesi/ 2020 Volume 8 Number 1 (September) http://doi.org/10.9770/jesi.2020.8.1(63)

blocks of the analog business model are replaced by modern elements of the digital business. Based on the analysis using the methods of analogy, abstraction, and a systematic approach, a loop of digital transformation was modeled as a continuous process reflecting the main stages of the transition, the necessary resources, and changes. The results obtained using the above scientific approaches and methods allow us to trace the process of digital transformation of a company and determine the direction of change of business models in the digital environment.

\section{Results}

The analysis of the content of digital transformation allows us to identify it as a continuous process of changes in the company, carried out using digital and other technologies, as well as organizational techniques for building a digital culture and achieving "digital maturity", which as a result will contribute to the creation and implementation of better and more competitive products (or services) for consumers, gaining competitive advantages and responding effectively to changes in the business environment. In accordance with the results of the analysis of a number of sources (Mitchell et al., 2003; Ivančić et al., 2019; Plaskova et al., 2019; Yemelyanov et al., 2018), it is safe to conclude that companies successfully operating in the digital environment objectively receive higher profits. In the near future, with a high probability, the digital economy will dictate the terms for the implementation of business processes of companies, which brings about the growing need of transferring business to digital platforms.

It should be noted that the main digital technologies that support the process of transforming companies around the world are: Big Data, Internet of Things, mobile robots, cloud computing, 3D scanning, 3D printing, smart devices, virtual and augmented reality, autonomous vehicles, handling complex events, prescriptive and in-depth analytics, gamification, machine-to-machine communication, biochips, programming emotions, social networks (Digital transformation for 2020 and beyond: a global telecommunications study, 2017; Digital transformation of the economy and industry, 2019; Dobrynin et al., 2016; Morrar et al, 2017; Polyakova et al, 2019; Rahman, 2018). The development of these and other innovative technologies is aimed at building a digital economy based on the ecosystem of integration of smart cyberphysical systems with society, provided by improved information and communication technologies.

According to a Ponemon Institute study (Bridging the digital transformation divide: leaders must balance risk \& growth, 2018), approximately $45 \%$ of foreign companies begin the digital transformation process without first developing an appropriate strategy, and $14 \%$ of organizations are not sure whether they are following some kind of strategy in the course of the digital transformation. At the same time, $41 \%$ of the respondents say that they are acting in accordance with a developed strategy, of which $57 \%$ note that their strategy includes integration with suppliers, intermediaries and other partners. In addition, respondents point out the importance of including in the transformation strategy issues related to data protection, as well as marketing policies aimed at retaining consumers and ensuring their loyalty.

The main reason motivating organizations to digital transformation is the desire to survive in a changing economic environment (Ismail et al., 2018; Dolganova et al., 2019; Zozulya, 2018). In general, the reasons motivating a business to transform can be classified into internal and external. Internal reasons include a decrease in sales, financial pressure from investors, the desire to expand the business and increase organizational flexibility, increase labor productivity, obtain long-term competitive advantages, etc. External triggers may consist in market changes, changes in consumer preferences, changes in the industry, emergence of new competitors, etc. 
The digital economy development level of a company (the so-called digital maturity) can be determined as follows:

- high level (all key business processes and company functions have been transferred to digital platforms);

- late middle level (most of the business processes and functions of the company are transferred to digital platforms);

- early middle level (planning and analysis of all the main digital processes and functions are carried out, but only a part of them is implemented);

- entry level (only a few business processes of the company have been digitized).

Based on the results of the analysis, six main functional areas of a company are formulated that require digital transformation (Figure 1).

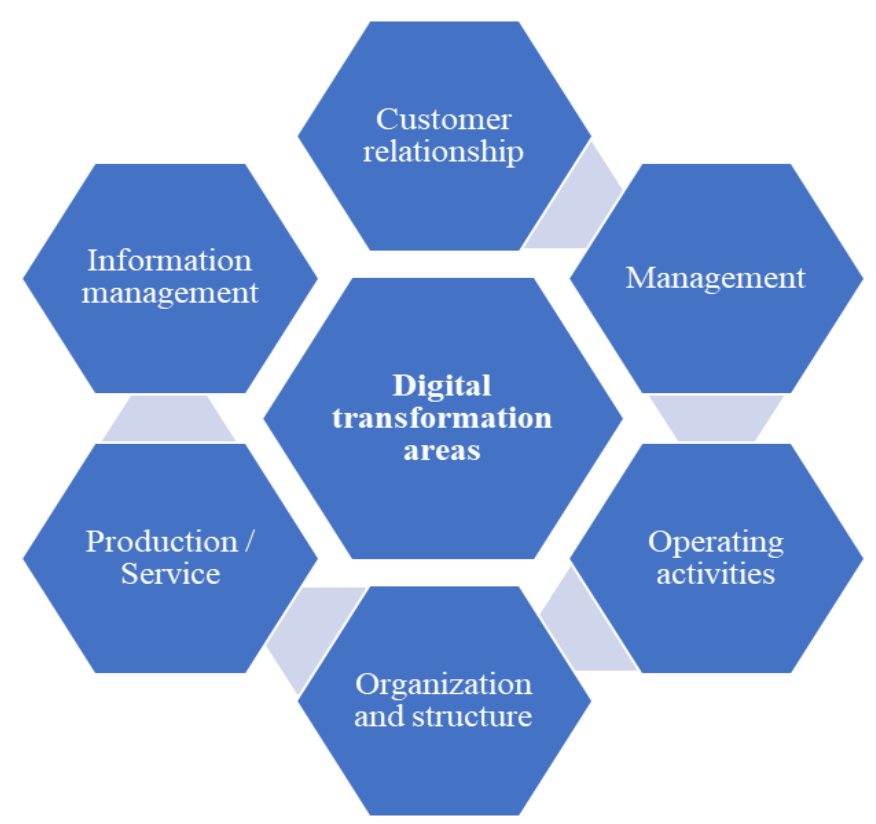

Figure 1. Functional areas of digital business transformation Source: compiled by the authors

The transformation areas shown in Figure 1 suggest the following changes for the company:

1. Entering a new level of interaction with the consumer: managing consumer experience, studying consumer preferences, a multi-channel marketing system. Digitalization significantly changes the behavior and preferences of consumers, which determines the need for constant market monitoring and communication with customers.

2. Active work with data: integration, analytics, protection of personal data, cybersecurity, etc.

3. The sphere of production and services: offering smart products and services, customization and personification of products, digital ecosystems.

4. Organizational transformation, providing increased flexibility, future job creation, digital thinking. Structural changes affect external and internal relations, and a change in the operation rate.

5. Changes in operating activities based on the use of digital technologies: the use of integrated information technologies, ensuring adaptability, building digital production, a smart logistics chain and a digital network of suppliers.

6. Management transformation based on changes in corporate development strategies, taking into account digital transformation and change management.

Transformation levels imply internal integration of organizational units, redesigning business processes, changing the corporate network, expanding the scope of activities, building an information security system, transforming 


\section{ENTREPRENEURSHIP AND SUSTAINABILITY ISSUES}

ISSN 2345-0282 (online) http://jssidoi.org/jesi/ 2020 Volume 8 Number 1 (September) http://doi.org/10.9770/jesi.2020.8.1(63)

the customer service process, transforming the business model (Berman, 2012; Rachinger et al., 2019; Oleinikova, 2019; Klochko et al., 2019). It is important to specify that the underdeveloped level of cybersecurity is a critical barrier to the successful process of digital transformation of companies (Tvaronavičienè 2018; Plèta et al., 2020). Data leakage can lead to negative consequences for the business, including damage to company software, reduced productivity, loss of intellectual property, loss of customer confidence, additional costs for investigation of violations and litigation, loss of reputation.

Analyzing the position of Russia among other countries in terms of readiness for the digital economy (Table 1), it should be noted that the level of digital development in the country is significantly inferior to the indicators of leaders (Digital Economy: 2019: a brief statistical digest, 2019).

Table 1 presents information on the use of the Internet in Russia for ordering goods, ERP-systems and CRMsystems in the work of organizations, as well as on the digital skills of the population (file transfer, the use of photo and video editing programs, text editors) in comparison with other countries. The data refer to 2017 or close periods for which information is available. As can be seen from the data given in Table 1, Russia is inferior to the UK, Germany, Finland, Sweden, France, the Czech Republic and Estonia in almost all the indicators. In Russia, the level of development of digital skills is by about 15 to $18 \%$ lower than in the above countries, and by 25 to $50 \%$ lower in using the Internet to order goods. A similar situation is observed in the application of ERP and CRM systems in the activities of organizations in the country, with the exception of the equally low level of use of ERP systems in Great Britain (19\%).

Table 1. Indicators of the use of digital technologies in Russia and worldwide

\begin{tabular}{|c|c|c|c|c|}
\hline \multirow{3}{*}{ Country } & \multicolumn{4}{|c|}{ Indicator } \\
\hline & \multirow{2}{*}{$\begin{array}{l}\text { Digital skills of the } \\
\text { population in } \% \text { of the } \\
\text { total population aged } \\
15 \text { to } 74 \text { years (average } \\
\text { value for all skills) }\end{array}$} & \multirow{2}{*}{$\begin{array}{l}\text { Using the Internet to } \\
\text { order goods in } \% \text { of the } \\
\text { total population aged } \\
15 \text { to } 74 \text { years }\end{array}$} & \multicolumn{2}{|c|}{$\begin{array}{c}\text { The use of ERP and CRM systems in } \\
\text { organizations in } \% \text { of the total number of } \\
\text { organizations }\end{array}$} \\
\hline & & & ERP-systems & CRM-systems \\
\hline Russia & 30 & 29 & 19 & 13 \\
\hline Great Britain & 58 & 82 & 19 & 32 \\
\hline Germany & 58 & 75 & 38 & 47 \\
\hline Finland & 63 & 71 & 39 & 39 \\
\hline France & 49 & 67 & 38 & 28 \\
\hline Czech Republic & 50 & 56 & 28 & 19 \\
\hline Sweden & 57 & 81 & 31 & 35 \\
\hline Estonia & 48 & 58 & 28 & 24 \\
\hline
\end{tabular}

Source: compiled by the author based on the Digital Economy: 2019 statistical digest

The aggregator of indicators of the country's readiness for digital transformation is the digitalization index, which combines the data set on the development of digital competencies among management and employees of companies, the use of digital technologies in the implementation of business processes, the use of data transmission and storage tools, Internet tools for advertising and product promotion, level of information security. The digitalization index, calculated for 2017, shows that Russia is in 31st place, lagging behind the leader (Finland) by 22 points. Besides Finland, Belgium, Denmark, the Republic of Korea, Holland, Sweden, Norway, Japan and Spain occupy leading positions. At a level with Russia scorring 28 points, are Bulgaria, Hungary and Romania (Digital Economy: Express Information. Business Digitalization Index). The values of the country's readiness indicators for the digital economy indicate the lack of efficiency and performance in the implementation of the government program for the development of the digital economy in Russia (Digital Economy of the Russian Federation Program). 


\section{ENTREPRENEURSHIP AND SUSTAINABILITY ISSUES}

ISSN 2345-0282 (online) http://jssidoi.org/jesi/ 2020 Volume 8 Number 1 (September) http://doi.org/10.9770/jesi.2020.8.1(63)

According to various scholars (Babkin et al., 2017; Zozulya, 2018; Digital Economy and Industry 4.0: Problems and Prospects, 2017), the problems of the development of the digital economy in Russia include the lack of a regulatory framework, infrastructure, a gap in the level of technological development in various industries, insufficient level of data cybersecurity development, lack of qualified personnel, and imperfect system of their training (Glotko et al., 2020). Among the main barriers to the development of digitalization, one can also single out the disinterest of top management of companies in the digital transformation of business, the lack of necessary IT skills among the staff, the use of outdated technologies, the lack of a digital culture and budget restrictions on the development and implementation of digital technologies (Oleinikova, 2019; Avdeyeva, 2019). At the same time, digital transformation implies objective advantages for the business: quick and affordable control over the business processes being implemented, increasing the speed of their execution, increasing productivity, the emergence of new sales markets, attracting investments, etc. However, the above-mentioned positive consequences of moving to the digital level do not currently serve as drivers for the transformation of many companies due to their inability and / or unwillingness to overcome the existing barriers.

The study shows that digital transformation involves not so much the use of digital technologies to achieve the goals of the company, but rather, complex changes in the business processes in the companies based on the use of digital technologies. Each company needs to develop a digital transformation strategy in accordance with its own goals and opportunities. A number of companies integrate the digital aspects of operations into the existing strategy; others tend to work on a separate strategy for digital development (Lerch \& Gotsch, 2015). Large organizations may need to make changes or develop three levels of strategies: corporate strategy, general business strategy and operational strategy (Ivančić et al., 2019).

The digital transformation of a company is based on the continuous improvement of business processes, standardization, internal and external integration using digital technologies. In the course of the transformation, companies offer consumers new products and services, consumers participate in the design, testing, production and distribution of new products, which requires a regular evaluation of customer satisfaction. In addition, any company striving for transformation needs appropriate human resources with the knowledge and skills to work effectively in the digital environment and able to quickly implement digital projects.

The digital ecosystem of a company is based on internal and external communications, as well as on digital platforms. Figure 2 shows the loop of the digital transformation of a business as a continuous process including certain stages and a cycle of changes. It is possible to return to the starting stages of the loop, and one can also see a cycle of changes in business processes at the stages from the development of a new business model to the adjustment of the strategy. The development and design of new products and services is carried out in the process of integration with partners, consumers and suppliers. Integration with educational institutions is also required to ensure the links between science and practice in the digital society, as well as the formation of a talent pool. All key business processes should be transferred to the digital level: robotics, communication, big data processing, etc. Cycling of the testing stages, expanding integration with partners, evaluating the effectiveness and adjusting the strategy is necessary at the initial stage to transfer all key business processes to the digital level, and then for the development of the company in the digital environment, the development, testing and implementation of improvement measures. It seems effective for the top management of the company to encourage initiative, innovative activity and staff creativity. The process of evaluating the innovativeness and effectiveness of the proposed projects and solutions based on the achievement of key performance indicators will allow for appropriate monitoring of the impact of changes, and to adjust the business model and development strategy. 


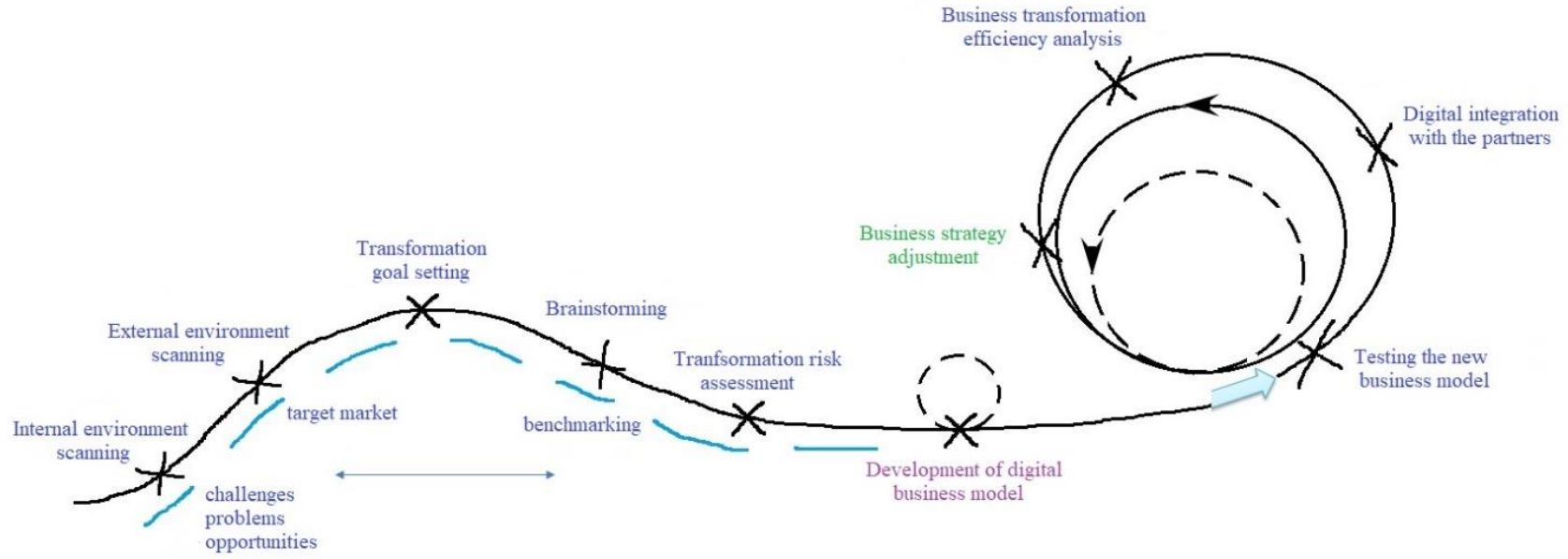

digital skills, communication with consumers

digital technologies, integration with partners

Figure 2. Digital business transformation loop Source: compiled by the authors

As can be seen from Figure 2, the transformation process involves the formation of new business models for the development of organizations. The main drivers of digital transformation need to be fixed in the business models of companies to provide a strategic vision of business transformation, implementation and evaluation of changes.

As a result of the study, the following key segments of business models of companies moving to the digital level were compiled:

1. Consumers (segmentation, customer relationships, customer involvement in the production chain, customer experience management, CRM, customer databases, social networks, digital profiles, etc.).

2. The company's offer (new or improved products and services, differentiation, customization of products, personification in accordance with the needs of customers, self-service and other advantages).

3. Resources and possibilities (digital technology, information, intellectual property, fixed assets, human and financial resources, organizational capabilities).

4. Partnerships and relations (interaction with industry partners and competitors, with the state, joint projects, joint services, alliances with suppliers, venture funds, banks, insurance companies, intermediaries, universities and outsourcing companies).

5. Channels of interaction with the external and internal environment (information and communication technologies: applications, augmented and virtual reality, logistics, intranet, video broadcasting in streamer mode, blogs, information retrieval systems, etc.).

6. Planning and analytics (information and analytical programs that provide planning, control and analysis of cash flows, including pricing processes, asset transactions, balance sheet management, cash and non-cash money flows, credit resources, discount systems, making payments, etc.).

7. Functions and business processes (the implementation of all the basic functions and business processes of the organization (functions of personnel, assets, knowledge, processes and innovations management, development, design, production, marketing, sales, services, logistics, accounting) at the digital instead of analog level: automation of production, automatic production control systems such as SCADA, ERP, electronic payments, lean manufacturing, robotics, cloud technology, blockchain technology, digital marketing, etc.) (Rosa et al., 2019).

The complexity of the digital restructuring of analog business models lies not only in the need to switch to the company functioning with the dominant use of digital technologies in solving everyday problems, but also in the 


\section{ENTREPRENEURSHIP AND SUSTAINABILITY ISSUES}

ISSN 2345-0282 (online) http://jssidoi.org/jesi/ 2020 Volume 8 Number 1 (September) http://doi.org/10.9770/jesi.2020.8.1(63)

importance of effective management and coordination of this process. The formation of new business models based on the key elements proposed in the work will allow companies to provide their main business processes with the required information, communication and technological component, as well as manage resources and functions in the new digital environment. It also seems appropriate to carry out further developments to determine the path of changes in the company's management area that are necessary for effective digital business transformation.

\section{Discussion}

Among the barriers that prevent foreign and domestic companies from successfully transforming, according to a number of scientists (Parviainen et al., 2017; Rachinger et. Al., 2019; Manyika J. Digital Economy: Trends, Opportunities and Challenges: extracts from McKinsey Global Institute Research ; Babkin, Chistyakova, 2017; Oleinikova, 2019), the following can be distinguished:

- undeveloped system for ensuring cybersecurity, protecting data and the company's business environment;

- underdeveloped information and communication system, IT-infrastructure, providing external and internal communication processes of the company, as well as maintaining databases;

- lack of experience and skills of top management of companies to carry out the necessary changes;

- lack of financial funding and required resources;

- Lack of a well-developed partnership system for working with suppliers, transport companies, financial and insurance organizations, as well as other partners;

- the complexity and intricacy of the business processes;

- lack of highly qualified personnel;

- insufficient competitiveness of the applied digital technologies;

- underestimation of potential risks (in particular, marketing and cybersecurity risks).

Overcoming the above barriers in a particular business must begin with effective planning and management. Many researchers (Babkin et al., 2017; Berman, 2012; Ismail et al., 2018) indicate that the main elements in the definition of a digital system are the exchange of knowledge and technologies, the company's ability to change and adapt to the external conditions. The main factors of successful digital transformation of a company include the presence of a competent leader, constant leadership support, the absolute concentration of business on the consumer, all kinds of new partnerships with key contractors, the use of effective personnel management techniques in a digital company, continuous work with data, and the use of digital technologies.

Adapting the approaches of a number of foreign researchers (Ritter \& Lettl, 2018; Ross et al., 2017); Business models of the digital economy (EFI Report), one can assume that an appropriate strategy is drawn up at the digital transformation planning level, a business model that determines the mechanisms, methods and necessary elements of the company's functioning is developed at the architectural level, and specific processes are described at the implementation level.

The digital business transformation loop presented in this work gives a conceptual idea of the main stages necessary for the transformation of elements and organizational changes, while the proposed segments of the digital business model provide the basic tools for doing business at the digital level, with the customized combination of the segments ensuring the gradual transition of the company business processes from analog to digital. The digitalization process insight and a strategic vision of the company's development path in the digital economy will allow top management to develop individual strategies and business models of the transformation. 


\section{Conclusion}

Modern business conditions offer and promote the idea of moving organizations to a digital format of activity for survival and optimization of key indicators in the context of the developing digital economy. The increased attention of scientists and practitioners to this research topic is determined by the main features of the digital economy, including the following:

- business productivity growth;

- high rate and pace of development;

- new competitive advantages due to the introduction of innovations;

- reduction of costs for the implementation of business processes;

- the emergence of new "smart" products and new markets;

- changes in the structure of professions in demand;

- the growing role of digital technologies providing businesses with an unlimited number of opportunities;

- development of digital platforms, electronic payment systems and tools, and social media.

The uniqueness of digitalization lies in its inherent properties, including globality, the significance of changes, rate, stimulation of increased competition, and technological influence on all spheres of society. However, the research has shown a number of problems that prevent companies from taking business processes to the digital level. These barriers in Russia include the following:

- the lack of an appropriate legal framework for doing business in the digital environment;

- the problem of limited budget and resource allocation;

- insufficient flexibility of organizations (especially large ones);

- lack of necessary partnerships;

- lack of innovation activity;

- insufficient level of interaction in the internal and external environment of the company;

- management problems (unwillingness to transform, lack of skills to manage changes and personnel in difficult conditions, etc.);

- the need to train personnel in new knowledge and skills required to implement the company's business processes at the digital level;

- undeveloped information security system.

The problems formulated are interdependent and negatively affect companies' attempts to build a model of effective functioning in the digital economy. Their study and analysis within the framework of a separately considered business will provide an opportunity to identify less costly and more effective digital transformation tools. The research investigates the content of digital transformation, visualizes the process of its implementation at a schematic level, and describes the key elements of the digital business models of companies based on the analysis of foreign and domestic scientific literature on the subject. Building a system of scientific knowledge and forming practical mechanisms for digitalizing a business require further studies of its economic aspects, including the impact of digital transformation on changing the competitiveness of a company, on personnel and business management, the problems of strategizing and roadmapping for digital transformation and business development in digital economy. 


\section{ENTREPRENEURSHIP AND SUSTAINABILITY ISSUES}

ISSN 2345-0282 (online) http://jssidoi.org/jesi/ 2020 Volume 8 Number 1 (September)

http://doi.org/10.9770/jesi.2020.8.1(63)

\section{References}

Akatkin Y., Karpov O., Konyavsky V. \& Yasinovskaya E. 2017. Digital economy: Conceptual architecture of a digital economic sector ecosystem. Business Informatics, 4(42), 17-28.

Abdrakhmanova, G. I., Vishnevsky, K. O., Gochberg, L. M., et al. 2019. Digital Economy: 2019: a brief statistical digest. Moscow: National Research. Higher School of Economics University (NRU HSE).

Amelin, S. V., Schetinina, I. V. 2018. Organization of Production in the Digital Economy Context. Production Organizer, 26(4), 7-18.

Asadullina, A. V. 2018. Digital Economy in Russia: Current Status and Development Problems. Russian Foreign Economic Bulletin, 6, 98112.

Avdeyeva, I. L., Polyanin, A. V., Golovina, T. A. 2019. Digitalization of Industrial Economic Systems: Problems and Consequences of

Modern Technologies. News of the Saratov University. Series Economics. Control. Law, 19(3), 238-245.

Babkin, A. V., Burkaltseva, D. D., Kosten, D. G., Vorobyov, Yu. N. 2017. Formation of Digital Economy in Russia: Essence, Features, Technical Normalization, Development Problems. Scientific and Technical State Papers of SPbSPU. Economics, 10(3), 9-25.

Babkin, A. V., Chistyakova, O. V. 2017. Digital Economy and its Impact on the Competitiveness of Business Structures. Russian Business, 18(24): 4088-4102.

Belk, R.W. 2013. Extended Self in a Digital World. Journal of Consumer Research, 40(3): 477-500.

Berman S.J., 2012. Digital transformation: opportunities to create new business models. Strategy \& Leadership, 40(2), $16-24$.

Bykanova, O.A. \& Akhmadeev, R.G. 2019. Universal VAT Loyalty Policy for B2B E-Commerce. Proceedings of the 34th International Business Information Management Association Conference, IBIMA 2019: Education Excellence and Management of Innovations through Sustainable Economic Competitive Advantage, 3046-3051.

Bloching, B., Leutiger, P., Oltmanns, T., Rossbach, C., Schlick, T., Remane, G., Quick, P. \& Shafranyuk, O. 2015. Die digitale Transformation der Industrie. Was sie bedeutet. Wer gewinnt. Was jetzt zu tun ist. Roland Berger Strategy Consultants and BDI, Munich, Berlin, pp. 52.

Boston Consulting Group: Digital transformation overview. URL: https://www.bcg.com/ru-ru/digital-bcg/digital$\underline{\text { transformation/overview.aspx }}$

Bridging the digital transformation divide: leaders must balance risk \& growth: Ponemon Institute Research Report, March 2018 , pp: 41.

Business models of the digital economy. EFIReport. 2016. URL: https://www.e-fi.de/fileadmin/Chapter_2016/2016_B3_EN.pdf

Digital Economy and Industry 4.0: Problems and Prospects: Proceedings of a scientific-practical conference with international participation / ed. Dr. econ. sciences, prof. A.V. Babkina. SPb: Polytechnic University Publishing House, 2017. \begin{tabular}{llllll}
$\begin{array}{l}\text { Digital } \\
\text { http://static.government.ru/media/files/9gFM4FHj4PsB79I5v7yLVuPgu4bvR7M0.pdf }\end{array}$ & Federation & Program. & URL: \\
\hline
\end{tabular}

Dokka, Z., Liubov, N., \& Filatova, I. 2020. Problems of oil refining industry development in Russia. International Journal of Engineering Research and Technology, 13(2), 267-270.

Digital Economy: Express Information. Business Digitalization Index. Moscow: NRU HSE Issue. URL: https://issek.hse.ru/data/2019/02/27/1193920132/NTI N 121 27022019.pdf

Digital transformation for 2020 and beyond: a global telecommunications study, EYGM Limited, 2017, pp: 40. 


\section{ENTREPRENEURSHIP AND SUSTAINABILITY ISSUES}

ISSN 2345-0282 (online) http://jssidoi.org/jesi/ 2020 Volume 8 Number 1 (September)

http://doi.org/10.9770/jesi.2020.8.1(63)

Digital Transformation of Economics and Industry: Proceedings of a Scientific and Practical Conference with Foreign Participation / Ed. Dr. econ. sciences, prof. A.V. Babkina. - SPb: POLYTEH-PRESS, 2019.

Dobrynin, A. P., Chernykh, K. Yu., Kupriyanovsky, V. P., Kupriyanovsky, P. V., Sinyagov S.A., 2016. Digital Economy - Various Ways to Effective Application of Technologies (BIM, PLM, CAD, IOT, Smart City, BIG DATA etc.). International Journal of Open Information Technologies, 4(1), 4-11.

Dolganova O.I., Deyeva E.A., 2019. Company's Readiness for Digital Transformation: Problems and Diagnostics. Business Informatics, 13(2), 59-72.

Galimova, M. P. 2019. Readiness of Russian Enterprises for Digital Transformation: Organizational Drivers and Barriers. Bulletin of Ural State Technical University. Science, education, economics. Series: Economics, 1(27): 27-37.

Gapsalamov, A. R., Merzon, E. E., Kuznetsov, M. S., Vasilev, V. L., \& Bochkareva, T. N. 2020. The education system in the context of socio-economic transformations. [O sistema educacional no contexto das transformações socioeconômicas] Periodico Tche Quimica, 17(34), 874-883.

Glotko, A. V., Polyakova, A. G., Kuznetsova, M. Y., Kovalenko, K. E., Shichiyakh, R. A., \& Melnik, M. V. 2020. Main trends of government regulation of sectoral digitalization. Entrepreneurship and Sustainability Issues, 7(3), 2181-2195. https://doi.org/10.9770/jesi.2020.7.3(48)

Ismail H.M., Khater M. \& Zaki M., 2018. Digital business transformation and strategy: what do we know so far? Working Paper. DOI: https://doi.org/10.13140/RG.2.2.36492.62086

Ivančić, L., Vuksić, V. \& Spremić, M. 2019. Mastering the digital transformation process: business practices and lessons learned. Technology Innovation Management Review, 9, 35-49.

Kazmina, I., Lukyanov, P., Zhminko, N., Savchenko, I., Yusupova, G., \& Zatsarinnaya, E. 2020a. Fourth industrial revolution-engineering innovations for labor productivity increasing. Talent Development and Excellence, 12, 477-487

Kazmina, I. V., Shafranskaya, C. Y., Saenko, I. I., Kozhemov, S. I., Gayazova, S. R., \& Zatsarinnaya, E. I. 2020b. An economic security management system of an enterprise in the digital economy. Talent Development and Excellence, 12, 454-466.

Khalin, V. G., Chernova, G. V. 2018. Digitalization and its Impact on the Russian Economy and Society: Advantages, Challenges, Threats and Risks. Management Consulting, 10(118), 46-63.

Klochko, E., \& Brizhak, O. 2019. Prospects of using virtual technologies in modern corporate business systems. Advances in Intelligent Systems and Computing, 726, 308-319. https://doi.org/10.1007/978-3-319-90835-9_36

Korableva, O. N., Kalimullina, O. V., \& Mityakova, V. N. 2019. Designing a system for integration of macroeconomic and statistical data based on ontology https://doi.org/10.1007/978-3-030-22868-2_12

Laužikas, M., Miliūtè, A. 2020. Liaisons between culture and innovation: comparative analysis of South Korean and Lithuanian IT companies. Insights into Regional Development, 2(2), 523-537. https://doi.org/10.9770/IRD.2020.2.2(2)

Lenka, S., Parida, V. \& Wincent, J., 2017. Digitalization capabilities as enablers of value co-creation in servitizing firms. Psychology \& Marketing, 34, 92-100.

Lerch, C. \& Gotsch, M., 2015. Digitalized product-service systems in manufacturing firms: a case study analysis. Research-Technology Management, 58(5), 45-52.

Manyika, J. Digital Economy: Trends, Opportunities and Challenges: extracts from McKinsey Global Institute Research. URL: https://www.ntia.doc.gov/files/ntia/publications/james_manyika_digital_economy_deba_may_16_v4.pdf

McKeown, I. \& Philip, G., 2003. Business transformation, information technology and competitive strategies: Learning to fly. International Journal of Information Management, 23(1), 3-24. 


\section{ENTREPRENEURSHIP AND SUSTAINABILITY ISSUES}

ISSN 2345-0282 (online) http://jssidoi.org/jesi/ 2020 Volume 8 Number 1 (September)

http://doi.org/10.9770/jesi.2020.8.1(63)

Minakhmetova, A. Z., Pyanova, E. N., Bochkareva, N. G., \& Borisov, V. V. (2020). Digital socialization of teenagers. Talent Development and Excellence, 12(3), 292-300.

Mitchell, D. W. \& Coles, C. 2003. The ultimate competitive advantage of continuing business model innovation. Journal of Business Strategy, 24(5), 15-21.

Morrar, R., Arman, H. \& Mousa, S. 2017. The fourth industrial revolution (Industry 4.0): a social innovation perspective. Technology Innovation Management Review, 7(11), 12-20.

Oleinikova, Yu. A., 2019. Challenges and Models of Business Development in the Context of the Digital Eeconomy Progression. Innovation Economy Issues, 9(4), 1415-1426.

Parviainen, P. Kääriäinen, J., Tihinen, M. \& Teppola, S. 2017. Tackling the digitalization challenge: How to benefit from digitalization in practice. International Journal of Information Systems and Project Management, 5(1), 63-77.

Petrenko, Y., Vechkinzova, E., Antonov, V. 2019. Transition from the industrial clusters to the smart specialization of the regions in Kazakhstan. Insights into Regional Development, 1(2), 118-128. https://doi.org/10.9770/ird.2019.1.2(3)

Plèta, T., Tvaronavičienė, M., Della Casa, S. 2020. Cyber effect and security management aspects in critical energy infrastructures. Insights into Regional Development, 2(2), 538-548. https://doi.org/10.9770/IRD.2020.2.2(3)

Popok, L., Ryabova, T., Bochkareva, N., Malinichev, D., Otto, O., \& Perednikh, L. 2020. Foreign experience of development of agrarian market. Talent Development and Excellence, 12(SpecialIssue3), 512-519.

Polyakova, A. G., Loginov, M. P., Strelnikov, E. V., \& Usova, N. V. 2019. Managerial decision support algorithm based on network analysis and big data. International Journal of Civil Engineering and Technology, 10(2), 291-300.

Plaskova, N. S., Prodanova, N. A., Samusenko, A. S., Erzinkyan, E. A., Barmuta, K. A., \& Shichiyakh, R. A. 2019. Investment decisions formation: Innovative assets. International Journal of Engineering and Advanced Technology, 9(1), 2913-2916. https://doi.org/10.35940/ijeat.A1213.109119

Prause, G., 2015. Sustainable business models and structures for Industry 4.0. Journal of Security and Sustainability Issues, 5(2), 159-169.

Rahman, P. A. 2018. Analysis of stationary availability factor of two-level backbone computer networks with arbitrary topology. Journal of Physics: Conference Series, 1015(2). https://doi.org/10.1088/1742-6596/1015/2/022016

Rachinger, M., Rauter, R., Müller, C., Vorraber, W. \& Schirgi E. 2019. Digitalization and its influence on business model innovation. Journal of Manufacturing Technology Management, 30(8), 1143-1160.

Ritter T. \& Lettl C., 2018. The wider implications of business-model research. Long Range Plan, 51(1): 1-8.

Rosa, A. T. R., Pustokhina, I. V., Lydia, E. L., Shankar, K., \& Huda, M. 2019. Concept of electronic document management system (EDMS) as an efficient tool for storing document. Journal of Critical Reviews, 6(5), 85-90. https://doi.org/10.22159/jcr.06.05.14

Ross, J. W., Sebastian, I. M. \& Beath, C. M. 2017. How to develop a great digital strategy. MIT Sloan Management Review, 58(2), 7-9.

Savina, N. N. 2019. Major factors of teachers' resistance to innovations. Ensaio, 27(104), 589-609. https://doi.org/10.1590/S0104$\underline{40362019002701807}$

Samusenko, A. S., Plaskova, N. S., \& Prodanova, N. A. 2020. The analysis of the external environment to determine the practical focus of applied research and development in the framework of innovation https://doi.org/10.1007/978-3-030-44703-8_27

Svahn, F., Mathiassen, L., Lindgren, R. \& Kane, G. C., 2017. Mastering the digital innovation challenge. MIT Sloan Management Review, 58(3), 14-16.

Tvaronavičienė M. 2018. Towards internationally tuned approach towards critical infrastructure protection. Journal of Security and Sustainability Issues, 8(2), 143-150. https://doi.org/10.9770/jssi.2018.8.2(2) 


\section{ENTREPRENEURSHIP AND SUSTAINABILITY ISSUES}

ISSN 2345-0282 (online) http://jssidoi.org/jesi/ 2020 Volume 8 Number 1 (September)

http://doi.org/10.9770/jesi.2020.8.1(63)

Voronkova, O. Y., Goloshchapova, L. V., Karabasheva, M. R., Khadzhaeva, A. R., Popok, L. E., \& Turgaeva, A. A. 2020. Development of the organic production sector in the regions: Economic, social and budgetary effect. Talent Development and Excellence, 12, 26-37.

Vial, G., 2019. Understanding digital transformation: A review and a research agenda. The Journal of Strategic Information Systems, 28(2), $118-144$.

Working Paper: Digital Economy $\quad$ - Facts \& https://ec.europa.eu/taxation customs/sites/taxation/files/resources/documents/taxation/gen info/good governance matters/digital/2014$\underline{03-13 \text { fact_figures.pdf }}$

Yemelyanov, V. A., Yemelyanova, N. Y., Morozova, O. A., \& Nedelkin, A. A. 2018. Specialized computer system to diagnose critical lined equipment. Paper presented at the Journal of Physics: Conference Series, 1015(5) https://doi.org/10.1088/1742-6596/1015/5/052032

Zozulya, D. M. 2018. Digitalization of the Russian Economy and Industry 4.0: Challenges and Prospects. Innovation Economy Issues, 8(1), 1-14.

Karine Alexandrovna BARMUTA, Doctor of Economic Sciences, Head of the Department of Economics and Management, Don State Technical University. Currently engaged in teaching economic disciplines related to innovation in organizations, organization economics, and crisis management. Research interests: enterprise development management, organizations innovation and investment activity, organization crisis management, digital economy, digital transformation.

ORCID ID: http://orcid.org/0000-0001-5460-4086

Elvir Munirovich AKHMETSHIN, Senior Lecturer of Economics and Management Department, Elabuga Institute of Kazan Federal University. 423604, 89, Kazanskaya Street, Elabuga, Republic of Tatarstan, Russian Federation. Author specializes in the study of the digital transformation of educational organizations. Currently engaged in teaching economics and management disciplines at the Faculty of Economics and Management EI KFU. Research interests: digital transformation of a university, digital educational platform, digitalization of educational services.

ORCID ID: $\underline{\text { http://orcid.org/0000-0002-2576-503X }}$

Iryna Yevheniivna ANDRYUSHCHENKO, Doctor of Economics, Professor of Finance, Banking and Insurance Department. National University "Zaporizhzhia polytechnic", Zhukovskogo str., 64, Zaporizhzhia, Zaporizhia Oblast, Ukraine. Currently engaged in teaching economics and management disciplines. Expert in the field of financial management. Research interests: business finance and strategic development; economic potential of enterprises.

ORCID ID: http://orcid.org/0000-0001-7421-2231

Asiyat Akhmedovna TAGIBOVA, Ph.D. in Sociology, Moscow State Institute of International Relations (MGIMO). Author currently Deputy President of the National Fund for Cultural Innovation of Russian Federation. The scope of activities includes coordinating the activities of the Fund, developing targeted programs, coordinating and monitoring the projects of the Fund. Research interests: social technologies, management sociology, sociology of culture, business and organizational culture, transnational corporations, sociocultural conflicts, corporate environment, corporate culture, social design, conflict management, leadership, cross-cultural management, internal corporate communications, digital economy, digital transformation of business.

ORCID ID: $\underline{\text { https://orcid.org/0000-0002-6731-5395 }}$ 


\section{ENTREPRENEURSHIP AND SUSTAINABILITY ISSUES}

ISSN 2345-0282 (online) http://jssidoi.org/jesi/ 2020 Volume 8 Number 1 (September) http://doi.org/10.9770/jesi.2020.8.1(63)

Galina Vladimirovna MESHKOVA, PhD, Candidate of Economic Sciences, Associate Professor, Department of Innovative Entrepreneurship, Bauman Moscow State Technical University. She leads the research work and practical training of students. Research interests: sustainable development of territories, innovations, technological and social business, investment, business valuation, economic security, corporate finance and international accounting.

ORCID ID: http://orcid.org/0000-0002-3795-0830

Angelina Olegovna ZEKIY, Doctor of Medical Science, Professor, Department of Prosthetic Dentistry, E.V. Borovsky Institute of Dentistry, I.M. Sechenov First Moscow State Medical University (Sechenov University), 8-2 Trubetskaya str., Moscow, 119991, Russian Federation. Research interests: medicine, dentistry, implantology, information technology in dentistry, digital dentistry, transformation of business processes, digital transformation, digital economy.

ORCID ID: http://orcid.org/0000-0002-8446-5088

Make your research more visible, join the Twitter account of ENTREPRENEURSHIP AND SUSTAINABILITY ISSUES:

@Entrepr69728810

Copyright (C) 2020 by author(s) and VsI Entrepreneurship and Sustainability Center

This work is licensed under the Creative Commons Attribution International License (CC BY).

http://creativecommons.org/licenses/by/4.0/

cc) (†) Open Access 